\title{
THE EFFECT OF BLACK RICE (Oryza sativa L. Indica) EXTRACT TO INCREASE ESTROGEN HORMONE ON PRE-MENOPAUSE OF FEMALE WHITE RATS (Rattus norvegicus)
}

\author{
Ardiansyah and Mahrun \\ Biology Education Study Program STKIP Al-Amin Dompu, NTB, Indonesia \\ Email: ardiansyah.bima@gmail.com
}

Accepted: May 08, 2021. Approved: January 29, 2022. Published: January 30, 2022

\begin{abstract}
The study aimed to determine the estrogenic activity of extracting ethanol from black rice (Oryza Sativa L. Indica) in pre-menopausal female white rats (Rattus norvegicus). Adaptation was carried out on 20 female rats (Rattus norvegicus) experimental rats for one week with a body weight of about 200-250 g. After one week, the experimental rats were divided into five treatment groups, with each group consisting of 4 rats. The positive control group (P1) was given Ethinyl estradiol orally at a dose of $9 \times 10-3 \mathrm{mg} / 200 \mathrm{~g} \mathrm{BB}$ in CMC-Na $1 \%$ as much as $3 \mathrm{~mL}$. The negative control group (P2) was given orally CMC-Na 1\% / 200g BW as $3 \mathrm{~mL}$. Test Group I (P3) were given orally an extract of Black Glutinous Rice mixed with ethanolic basil leaves $96 \%$ with a dose equivalent to $1 \mathrm{~mL}$ of thick extract in an amount of $0.8 \mathrm{~g} / 200 \mathrm{~g} \mathrm{BW}$ in $1 \% \mathrm{CMC}-\mathrm{Na}$ as much as $3 \mathrm{~mL}$. Test Group II (P4) was given an extract of the ethanol substance in Black Rice with a dose equivalent to $2 \mathrm{~mL}$ of thick extract in $1.6 \mathrm{~g} / 200 \mathrm{~g}$ $\mathrm{BW}$ in $3 \mathrm{~mL}$ of $1 \%$ CMC-Na orally. Test Group III (P5) was given orally Black Glutinous Rice in a dose equivalent to $4 \mathrm{~mL}$ of thick extract in $3.2 \mathrm{~g} / 200 \mathrm{~g} \mathrm{BB}$ in CMC-Na $1 \%$ as much as $3 \mathrm{~mL}$. The treatments were carried out orally for one estrous cycle begins during the estrus phase. Uniformity during the estrus phase was carried out using the Whitten-Method Effect. It aims to observe changes in the vagina to determine the estrus cycle by placing the male rat cage on top of the female rat cage. Conclusions from the results of this study show that the Black Glutinous Rice (Oryza Sativa L. Indica) extract treatment can increase the estrogenic activity of white rats pre-menopausal females (Rattus norvegicus). A $0.8 \mathrm{~g} / 200 \mathrm{~g}$ BW dose can prolong the estrus cycle and increase vascularity and ovarian weight compared to the negative control (CMC-Na1\%). The treatment with the lowest concentration was equivalent to the positive control of Ethinyl estradiol (9x10-3mg/200g BW). This test indicates that giving $96 \%$ ethanol extract of Black Glutinous Rice causes an increase in the hormone estrogen in the estrus phase, which tends to prolong the estrus cycle.
\end{abstract}

Keywords: Female Rats (Rattus norvegicus), Black Sticky Rice (Oryza Sativa L.) Extract, Estrogen Hormone, Pre-Menopause.

\section{INTRODUCTION}

Rice is a very important food ingredient for the world community. There are three types of rice: white, red and black rice. Black rice contains anthocyanin compounds which are included in the type of flavonoid and phenolic compounds. The content of polyphenol antioxidants in rice is also influenced by genotype [1].

Black rice contains anthocyanins. Anthocyanins are included in the flavonoid group, a group of polyphenols that are widely used in food because of their biological effects and are present in the form of glycosides or related to sugar components (mono, di, or triglycoside [2]).

With alpha and beta bonds, antioxidants are substances needed to neutralize free radicals and prevent damage caused by free radicals by complementing the electron deficiency of free radicals and inhibiting the chain reaction of the formation of free radicals that can cause oxidative stress [3].

Based on the previous research above, the purpose of this study was to determine the estrogenic activity of the $70 \%$ ethanol extract of Wangi Rice (Oryza sativa L) in pre-menopausal female white rats (Rattus norvegicus), also to observe ovarian and uterine vascularization in the estrus phase [4].

Plants that contain high levels of phenolic and anthocyanin compounds are Vaccinium species (such as blueberries, cranberries, and bilberries), grapes, apples, black rice (Oryza sativa L. indica), eggplant, and red cabbage. Black rice is a food ingredient that is commonly found in developing countries and $95 \%$ is produced by countries in the Asian region. Black rice contains phenol and anthocyanin compounds which are higher than other types of rice, such as white rice and brown rice [5].

Phenol compounds in black rice ethanol extract can prevent cancer growth because it can reduce cyclin activity and inhibit ERK, JNK, MAPK, NF$\kappa \mathrm{B}$ and AP1 pathways. Anthocyanins in black rice ethanol extract can inhibit the PI3K pathway. Inhibition of the PI3K pathway by ethanolic extract of black rice caused a decrease in PKB phosphorylation, resulting in a decrease in proproliferative and antiapoptotic activity. Anthocyanins can also decrease the activity of cyclin proteins, NF- $\kappa \mathrm{B}$ and AP1 [6].

Rats (Rattus sp) are harmful rodents and are pests of farmers' crops. In addition to being a harmful pest, these animals also endanger human life. As carriers of dangerous diseases, these animals 
can transmit diseases such as bubonic plague and leptospirosis. These animals live in groups in a hole. One group can reach 200 tails. These rats are found in coconut plantations, ditches and meadows. This rat has a very sharp sense of smell [8].

The reproduction of mice is extraordinary. Once giving birth, mice can produce up to 15 tails, but the average is 9 tails. Other names for this animal in various regions in Indonesia, among others: in Minangkabau it is called mice, while the Sundanese call it beurit. The most famous rat is the brown rat, which is a pest in agricultural businesses and food stored in warehouses. Albino rats (white rats) are widely used as experimental animals in the laboratory [9].

Learning to identify rats begins with learning about taxonomy, the science of classification theory which includes the basics, principles and procedures/rules as well as analysis of variations. In simpler terms, taxonomy can be thought of as the science of naming an organism. The name of an organism is very important, because without a name we cannot talk about an animal that we mean. In addition, in an organism, inherent all the characteristics and characteristics - certain characteristics. The name of the species (species) always consists of two names or binomials. In addition, scientific names must use Latin or a Latinized language. Such rules are contained in the "International Code of Zoological Nomenclature abbreviated as ICZN". Binomial names are Linnaeus' findings that are very important in the world of taxonomy because binomial names prevent duplication of names [10].

In the world of rodents, there are 29 tribes/families, 468 genera and 2,052 species, while in Indonesia there are three tribes: Scuridae, Muridae and Hystricidae. The three tribes were classified based on the consistency of the hair, the thickness and length of the hair growing on the tail, and the presence and size of the orbital foramen. Members of the Sciuridae (tribe squirrels) in Indonesia have 54 species, Muridae (tribe rats) have 171 species and Hystricidae (tribe hedgehogs) have 6 species. In Java, the Sciuridae tribe has 8 genera, 12 species; There are 10 genera Muridae, 22 species. Hystricidae only has a single member. Thus, in Java there are 35 types of rodent members. Sciuridae has 2 sub-tribes, i.e., Scurinae (squirrels) and Petauristinae (flying squirrels). Muridae has a single tribal child [11].

Rodentia comes from the Latin "rodere" which means rodent which is characterized by the presence of two upper and lower incisors that do not have tooth roots, relatively large and long and continue to grow throughout their life, no fangs, there is a gap between the incisors and molars. . Due to the growth of incisors throughout their life, rodents must maintain the length of their incisors so that the incisors do not penetrate the skull. The trick is that rodents have to sharpen their incisors by crippling hard objects around them. Therefore, rats as a type of rodent act as pests in both agricultural and urban areas [12]

Guard hair; rat hair that is longer than the under fur. Some of the guard hair is in the form of thorns, some are not like Rattus norvegicus and Bandicota indica. Thorn-shaped guard hairs are usually broad at the base and narrow at the ends. The consistency of the guard hair in the form of spines is usually a broad base and narrow ends. The consistency of the guard hair in the form of spines can be fine to coarse and even stiff as in most members of Maxomys, Rattus exulans and some members of Niviventer. In Rattus Tanezumi, the guard hair is not stiff in the form of spines [13].

Hair color: it is necessary to pay attention to whether the hair color of the back and abdomen is significantly different (contrast) or not as in house mice (R. tanezumi). In mice (R. norvegicus) there was no significant difference between belly and back hair color, on the other hand, in the thicket rat (Rattus tiomanicus) and rice field rat (Rattus argentiventer) the belly and back colors were significantly different. The color of the belly hair is pure white as in R. tiomanicus, there is gray as in Mus sp, Rattus Exulans, R. tanezumi and R. norvegicus [14].

Nipple formula: the front number shows the number of pairs of nipples that grow on the chest, while the back numbers show the pairs of nipples that grow on the stomach as an example of $\mathrm{R}$. tanezumi's nipple formula: $\mathrm{M}=2+3$ [15].

Tail color: some types of mice have the color of the lower and upper surfaces are not the same or bicolored as in all members of Maxomys, most Niviventer and some Leopoldamys. Upper incisors: color and shape of incisors. There are three types of incisors, namely prodont when the incisor axis is facing forward, opisthodon when the incisor axis is pointing backwards, orthodont when the incisor axis is vertical [16].

Foramina incisivum: position towards the front molars (some types of foramina incisivum reach the front molars as in all members of Rattus, some are not like in all members of Maxomys. In addition to the position of the foramina, the size of the foramina also needs to be considered, for example, all members of Maxomys have foramina that are short and wide. Back of the palate (palatum): positioned against the back molars Some types of back palate mice are located behind the back molars as in Rattus members, but some are located in front of the back molars as in Maxomys [17].

The direction of the axis of the incisors can also be used to help identify mice, for example there are incisors whose prodon means that the axis of the incisors points forward, orthodontist means that the axis of the incisors is perpendicular and 
opisthokonts means that the axis of the incisors is directed backwards [18].

The size of the zygomatic plate is also important in identification, for example the zygomatic plate of $\mathrm{R}$. argentiventer is wider than that of $\mathrm{R}$. tiomanicus and R. tanezumi. In addition to the size, shape and direction of the front of the zygomatic plate can also distinguish the type [19].

\section{RESEARCH METHODS}

The method used in this study is the Whitten Effect method, which aims to observe changes that occur in the vagina to determine the estrus cycle by placing the male rat cage above the female rat cage. The experimental class will be given an extraction test of black rice (Oryza sativa I) with ethanol, while the control class will be pre-menopausal female white rats (Rattus norvegicus) [20].

\section{RESULTS AND DISCUSSION}

Based on the results of the calculation in table 3, the ethanol extract of Black Rice that showed the highest total ethanol content was sample 1, which was $8.53 \pm 0.208 \%$. From these results 7 samples of black rice can be declared positive for containing ethanol, where ethanol has many benefits in fields such as perfumes, food flavours, food coloring, and medicine.

Estrus is a phase of the lust period. The duration of estrus in rats is 9-20 hours and the estrus cycle lasts for four to six days. The estrus cycle is divided into four phases, namely proestrus, estrus, metestrus, and diestrus. The results of the extract test on the length of the estrus cycle were conducted by observing the cells found in the vaginal smear microscopically which could be seen in the proestrus phase characterized by multinucleated epithelial cells. This phase signifies the coming of lust. Vaginal smear preparations in the estrus phase are characterized by the formation of cornified cells (cells gore) as an illustration of the number of mitoses that occur in the vaginal mucosa. Towards the end of estrus, the vaginal lumen forms horny cells with degenerating nuclei. In the metestrus phase, the ovary is reduced and the ovary contains a corpus luteum containing luteinizing cells and small, nonnucleated follicles. The diestrus phase is dominated by leukocytes and nucleated epithelial cells begin to appear.

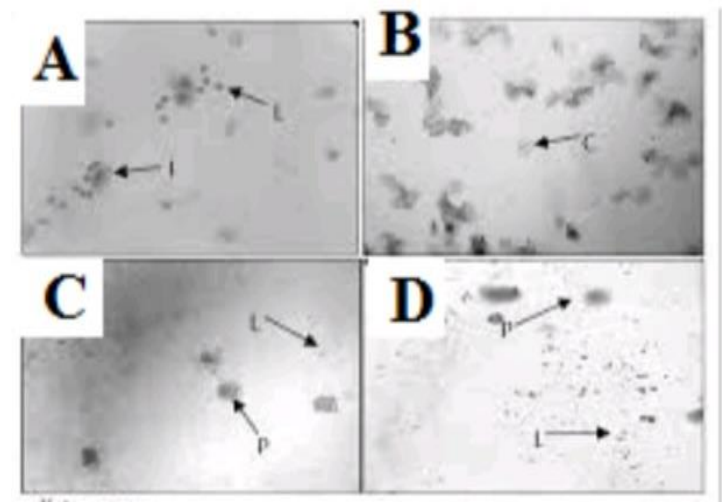

Figure 1. Schematic view of vaginal smear in the estrous cycle (A) Diestrus, (B) Proestrus, (C)

Estrus, (D) Metestrus (Bognara \& Donnel, 1988)

Note:

A. Proestrus: there are ordinary epithelial cells

B. Estrus: there are horned cells (cornified)

C. Diestrus: there are ordinary epithelial cells and many leukocytes

D. Matestrus (if any): there are many horny epithelial cells and leukocytes, then also ordinary epithelial cells

Table 1. Changes in the vaginal epithelium during the estrus cycle

\begin{tabular}{|c|c|c|c|c|c|}
\hline \multirow{2}{*}{$\begin{array}{l}\text { estrus cycle } \\
\text { phase }\end{array}$} & \multirow{2}{*}{$\begin{array}{l}\text { Phase } \\
\text { length } \\
\text { (hours) }\end{array}$} & \multicolumn{4}{|c|}{ Vaginal review from various sources } \\
\hline & & $\begin{array}{l}\text { Dalal et al. } \\
(2001)\end{array}$ & $\begin{array}{l}\text { Smith \& } \\
\text { Mangkoewidjojo (1988) }\end{array}$ & $\begin{array}{l}\text { Nalbandov } \\
(1999)\end{array}$ & $\begin{array}{l}\text { Syahrum, } \\
\text { et.al. (1994) }\end{array}$ \\
\hline Proestrus & 12 & $\begin{array}{l}\text { Epithelial } \\
\text { cells, } \\
\text { leukocytes } \\
\text { a little }\end{array}$ & Nuclear epithelial cells & $\begin{array}{l}\text { Nuclear } \\
\text { epithelial cells }\end{array}$ & $\begin{array}{l}\text { Nuclear epithelial } \\
\text { cells, few } \\
\text { leukocytes }\end{array}$ \\
\hline Estrus & 12 & $\begin{array}{l}\text { More and more } \\
\text { horn cells }\end{array}$ & Epithelial cells horn & Cornified cells & $\begin{array}{l}\text { Multi-horned } \\
\text { epithelial cells }\end{array}$ \\
\hline Metestrus & 12 & $\begin{array}{l}\text { Horn cells, } \\
\text { more } \\
\text { leukocytes }\end{array}$ & $\begin{array}{l}\text { cornified epithelial } \\
\text { cells, leukocytes present }\end{array}$ & $\begin{array}{l}\text { Cornified cells } \\
\text { between } \\
\text { leukocytes }\end{array}$ & $\begin{array}{l}\text { Epithelial cells } \\
\text { horns, more } \\
\text { leukocytes }\end{array}$ \\
\hline Diestrus & 65 & $\begin{array}{l}\text { Leukocytes } \\
\text { and cells } \\
\text { nucleated } \\
\text { epithelium }\end{array}$ & $\begin{array}{l}\text { Leukocytes and cells } \\
\text { Epithelium }\end{array}$ & $\begin{array}{l}\text { Nuclear } \\
\text { epithelial cells } \\
\text { and leukocytes }\end{array}$ & $\begin{array}{l}\text { Nuclear epithelial } \\
\text { cells } \\
\text { and leukocytes }\end{array}$ \\
\hline
\end{tabular}


Table 2. Extraction Results on Seven Black Rice Samples

\begin{tabular}{|c|c|c|c|c|c|}
\hline Sample & Absorbance & Concentration $(\mathrm{mg} / \mathrm{ml})$ & $\%$ Concentration & Average $\%$ Concentration & SD \\
\hline & 0,727 & 0,086 & 8,65 & & \\
\hline \multirow[t]{3}{*}{1} & 0,728 & 0,087 & 8,66 & \multirow{3}{*}{8,53} & \multirow[t]{3}{*}{0,208} \\
\hline & 0,699 & 0,083 & 8,29 & & \\
\hline & 0,7 & 0,083 & 8,30 & & \\
\hline \multirow[t]{3}{*}{2} & 0,7 & 0,083 & 8,30 & \multirow[t]{3}{*}{8,11} & \multirow{3}{*}{0,343} \\
\hline & 0,653 & 0,077 & 7,71 & & \\
\hline & 0,672 & 0,079 & 7,95 & & \\
\hline \multirow[t]{3}{*}{3} & 0,672 & 0,079 & 7,95 & \multirow[t]{3}{*}{7,69} & \multirow[t]{3}{*}{0,446} \\
\hline & 0,611 & 0,072 & 7,18 & & \\
\hline & 0,531 & 0,062 & 6,16 & & \\
\hline \multirow[t]{3}{*}{4} & 0,531 & 0,062 & 6,16 & \multirow[t]{3}{*}{6,03} & \multirow[t]{3}{*}{0,227} \\
\hline & 0,5 & 0,058 & 5,77 & & \\
\hline & 0,445 & 0,051 & 5,08 & & \\
\hline \multirow[t]{3}{*}{5} & 0,443 & 0,051 & 5,05 & \multirow[t]{3}{*}{4,97} & \multirow[t]{3}{*}{0,169} \\
\hline & 0,421 & 0,048 & 4,77 & & \\
\hline & 0,322 & 0,035 & 3,52 & & \\
\hline \multirow[t]{3}{*}{6} & 0,342 & 0,038 & 3,77 & \multirow[t]{3}{*}{3,74} & \multirow[t]{3}{*}{0,210} \\
\hline & 0,355 & 0,039 & 3,94 & & \\
\hline & 0,457 & 0,052 & 5,23 & & \\
\hline \multirow[t]{2}{*}{7} & 0,461 & 0,053 & 5,28 & \multirow[t]{2}{*}{5,02} & \multirow[t]{2}{*}{0,403} \\
\hline & 0,404 & 0,046 & 4,56 & & \\
\hline
\end{tabular}

(Source: Data Analysis Results)

The estrus cycle time is shown in Table 1 which shows that the treatment of $96 \%$ ethanol extract on Black Rice with the lowest concentration experiencing estrus for 165 hours (closer to 7 days) was equivalent to the positive control and the highest concentration. The total duration of the estrus cycle (proestrus, estrus, metaestrus and diestrus) is 4-5 days. The negative control treatment (CMC-Na1\%) gave the shortest estrous cycle time of 107 hours compared to the other four treatment groups. Statistical test results showed that $1 \%$ CMC$\mathrm{Na}$, ethinyl estradiol, $96 \%$ ethanol extract in Black Rice at a dose of $0.8 \mathrm{~g} / 200 \mathrm{~g} \mathrm{BW} ; 1.6 \mathrm{~g} / 200 \mathrm{~g} \mathrm{BW}$ and
$3.2 \mathrm{~g} / 200 \mathrm{~g}$ BW gave a very significant effect on increasing (longer) estrous cycle time $(\mathrm{P}<0.01)$.

The results of Duncan's test to determine the difference between treatments showed that all treatments with $96 \%$ ethanol extract in Black Rice had the same effect as ethinyl estradiol $9 \times 10-3$ $\mathrm{mg} / 200 \mathrm{~g} \mathrm{BW}$ as a positive control on prolonging the estrus cycle in pre-menopausal female rats. Through the administration of the lowest dose of $0.8 \mathrm{~g} / 200 \mathrm{~g}$ $\mathrm{BW}$, the effect was equivalent to the positive control with a very significant difference in prolonging the estrus cycle. The data for measuring the time of the estrous cycle can be seen in Table 3. below.

Table 3. Estrous Cycle Time

\begin{tabular}{llllll}
\hline Number of Repeats & \multicolumn{5}{c}{ Cycle Length (hours)Treatment } \\
& P1 & P2 & P3 & P4 & P5 \\
\hline 1 & 165 & 100 & 165 & 159 & 174 \\
2 & 163 & 120 & 165 & 165 & 165 \\
3 & 165 & 104 & 165 & 174 & 165 \\
4 & 164 & 104 & 165 & 165 & 165 \\
Total & 657 & 428 & 660 & 663 & 669 \\
Average & $164.3^{\mathrm{a}}$ & $107^{\mathrm{a}}$ & $165^{\mathrm{ac}}$ & $165.75^{\mathrm{ac}}$ & $167.3^{\mathrm{ac}}$ \\
\hline
\end{tabular}

Note: Numbers followed by the same superscript on the same line show no significant difference $(\mathrm{P}>0.05)$.

The results of this test indicate that the administration of Black Rice Ethanol Extract causes an increase in the hormone estrogen in the estrus phase so that it tends to prolong the estrus cycle.

\section{CONCLUSION}

Results Treatment of $96 \%$ ethanol extract on Black Rice (Oryza Sativa L.) can increase the estrogenic activity of pre-menopausal female white rats (Rattus norvegicus). At a dose of $0.8 \mathrm{~g} / 200 \mathrm{~g} \mathrm{BW}$ can prolong the estrous cycle, also increase 
vascularity and increase ovarian weight compared to negative controls (CMC-Na1\%). The treatment with the lowest concentration was equivalent to the positive control of ethinyl estradiol (9x10-3mg/200g $\mathrm{BW})$.

\section{REFERENCES}

[1] Yodmanee, S., Karrila, T. T., \& Pakdeechanuan, P. (2011). Physical, chemical and antioxidant properties of pigmented rice grown in Southern Thailand. International food research journal, 18(3).

[2] Effendi, E. M., Hera, H. M., \& MI, M. L. (2015). Aktivitas estrogenik ekstrak etanol 70\% herba kemangi (Ocimum americanum 1.) pada tikus putih betina (Rattus norvegicus) premenopause. FITOFARMAKA: Jurnal Ilmiah Farmasi, 5(1), 1-9.

[3] Pengkumsri, N., Chaiyasut, C., Saenjum, C., Sirilun, S., Peerajan, S., Suwannalert, P., ... \& Sivamaruthi, B. S. (2015). Physicochemical and antioxidative properties of black, brown and red rice varieties of northern Thailand. Food Science and Technology, 35, 331-338.

[4] Abidin, Z. (2017). Effect of Ethanol Extract of Oryza sativa L. indica on Protein Kinase B Activity and CA 15-3 Serum Level in in Female Sprague dawley Rats. eJournal Kedokteran Indonesia, 187-90.

[5] Maheshwari, H., \& Satyaningtijas, A. S. (2010). Aktivitas ekstrak metanol buah adas (Foeniculum vulgare Mill) terhadap lama siklus estrus serta bobot uterus dan ovarium tikus putih.

[6] Calame, T. E. L., Kusmiyati, K., \& Merta, I. W. (2021). The Effect of Young Papaya Seed Extract on The Motility and Abnormality of Male Mice Spermatozoes (Mus musculus). Jurnal Pijar Mipa, 16(4), 555-561.

[7] Andayani, Y., Aini, S. R., Pratama, I. S., Amalia, N. M. R., \& Hidayat, L. H. (2021). Studi Preeliminari Suplementasi Produk Herbal Antidiabetes Terhadap Kontrol Glikemik Pasien Diabetes Mellitus Tipe II. Jurnal Pijar Mipa, 16(1), 91-96.

[8] Puspitasari, L., Swastini, D. A., \& Arisanti, C. I. A. (2013). Skrining fitokimia ekstrak etanol 95\% kulit buah manggis (Garcinia mangostana L.). Jurnal Farmasi Udayana, 2(3), 1-4.

[9] Suyanto, A., Yoneda, M., Maryanto, I., \& Maharadatunkamsi \& Sugardjito, J. (1998). Checklist of the mammals of Indonesia. LIPIJICA Joint Project for Biodiversity Conservation in Indonesia. LIPI, Bogor.

[10] Putri, H. N., Budiarto, B., Arimbi, A., Suwanti, L. T., Kusnoto, K., \& Soeharsono, S. (2019). Heminthiasis in a Wild Rats (Rattus sp.) in Surabaya. Journal of Parasite Science, 3(2), 73-76.
[11] Nafisah, M., Tukiran, S., \& Hidayati, N. (2014). Phytochemical Screening Test On hexan, Chloroform and Methanol Extracts of Patikan Kebo (Euphorbiae hirtae). In Prosiding Seminar Nasional Kimia (pp. 279-286)..

[12] Saraswati, F. N. (2015). Uji Aktivitas Antibakteri Ekstrak Etanol 96\% Limbah Kulit Pisang Kepok Kuning (Musa balbisiana) Terhadap Bakteri Penyebab Jerawat (Staphylococcus epidermidis, Staphylococcus aureus, dan Propionibacterium acne). Skripsi, UIN Syarif Hidayatullah, Jakarta.

[13] Triyasmono, L., Cahaya, N., \& Sari, Y. N. (2015). Aplikasi FTIR dan Kemometrika PLSR (Partial Least Square Regression) pada Prediksi Kadar Flavonoid Total Bungur (Lagerstroemia Speciosa Pers.) Khas Kalimantan. In Prosiding Seminar Nasional \& Workshop "Perkembangan Terkini Sains Farmasi \& Klinik, Bogor.

[14] Sharma, S. M., \& Bhadange, D. G. (2013). A review on study of medicinal uses of some aromatic plants. World J. Microb. Biot, 1-14.

[15] Khazaei, M., Montaseri, A., Khazaei, M. R., \& Khanahmadi, M. (2011). Study of Foeniculum vulgare effect on folliculogenesis in female mice. International journal of fertility \& sterility, 5(3), 122.

[16] Swandana, I. (2010). Uji Efikasi Ekstrak Biji Buah Mahkota Dewa (Phaleria macrocarpa (Scheff.) Boerl) Untuk Pengawetan Kayu Kelapa (Cocos nucifera L) Dengan Metode Rendaman Dingin Terhadap Serangan Rayap Kayu Kering Cryptotermes cynocephalus Light.

[17] Tascioglu, C., Yalcin, M., Sen, S., \& Akcay, C. (2013). Antifungal properties of some plant extracts used as wood preservatives. International Biodeterioration \& Biodegradation, 85, 23-28.

[18]Azis, A., \& Hut, S. (2012). Uji Efektifitas Ekstrak Tumbuhan Kumis Kucing (Orthosiphon Sp.) Sebagai Pengawet Alami Kayu Terhadap Serangan Rayap Kayu Kering Cryptotermes sp (Doctoral dissertation, Universitas Gadjah Mada).

[19] Triyasmono, L., Cahaya, N., \& Sari, Y. N. (2015). Aplikasi FTIR dan Kemometrika PLSR (Partial Least Square Regression) pada Prediksi Kadar Flavonoid Total Bungur (Lagerstroemia Speciosa Pers.) Khas Kalimantan. In Prosiding Seminar Nasional \& Workshop "Perkembangan Terkini Sains Farmasi \& Klinik, Bogor.

[20] Ochiogu, I. S., Oguejiofor, C. F., \& Nwagbo, A. N. (2009). Males' non-enhancement of bruce and whitten effects in female albino mice-Mus musculus. Animal Research International, 6(3). 
[21] Umami, S. R., Hapizah, S. S., Fitri, R., \& Hakim, A. (2016). Uji penurunan kolesterol pada mencit putih (Mus musculus) secara invivo menggunakan ekstrak metanol umbi talas (Colocasia esculenta L) sebagai upaya pencegahan cardiovascular disease. Jurnal Pijar Mipa, 11(2). 